Original Article (short paper)

\title{
Prevalence of body image dissatisfaction and association with teasing behaviors and body weight control in adolescents
}

\author{
Andressa Ferreira da Silva ${ }^{1}$ (D), Mikael Seabra Moraes $^{1}$ (D), Priscila Custódio Martins ${ }^{1}$ (D), \\ Eduarda Valim Pereira² (D), Joni Marcio de Farias² (D), Diego Augusto Santos Silva ${ }^{1}$ \\ Universidade Federal de Santa Catarina, Centro de Desportos, Núcleo de Pesquisa em \\ Cineantropometria e Desempenho Humano, Florianópolis, SC, Brasil. \\ ${ }^{2}$ Universidade do Extremo Sul Catarinense, Mestrado em Saúde Coletiva, Criciúma, SC, Brasil.
}

\begin{abstract}
Aims: The objective was to estimate the prevalence and the factors of behaviors of provocation and control of the weight associated with dissatisfaction with the body image among adolescents. Methods: Cross-sectional study with 580 adolescents ( 11 to 17 years old) from Criciúma, Brazil. The body image was evaluated by the silhouettes scale and the behaviors of provocation and weight control by questionnaires. A multinomial logistic regression was used ( $\mathrm{p} \leq 0.05$ ). Results: Of the total number of adolescents, $48.6 \%$ were dissatisfied with being overweight (male $47.9 \%$, female $49.3 \%$ ) and $22.9 \%$ dissatisfied with thinness (male $23.8 \%$, female $22.1 \%$ ). Male adolescents who were dissatisfied with being overweight were more likely to be joked and laughed at because of their appearance and lower chances of being nicknames due to their size or body weight, while those who were unsatisfied with being thin were more likely to joke and laughter because of the appearance, compared to satisfied. Female adolescents who were dissatisfied with being overweight were more likely to be laughed at because they were uncoordinated and without food for $24 \mathrm{~h}$, while those who were unsatisfied with being thin were less likely to be joking and laughing because of their appearance and higher chances to be the targets of laughter because they are uncoordinated, compared to those that are satisfied. Conclusion: The dissatisfaction with body image was associated with different behaviors of provocation and weight control according to sex.
\end{abstract}

Keywords: adolescent health, lifestyle, bullying, students.

\section{Introduction}

Body image can be understood as the relationship between body and cognitive processes as individual beliefs, values, and attitudes ${ }^{1}$. Individuals with body image disorders may be dissatisfied with their body image due to overweight or thinness ${ }^{2}$. Body image perception is preponderant in adolescent self-acceptance, as body image dissatisfaction can generate inappropriate attitudes that compromise health and adequate growth ${ }^{3}$. Studies in Brazil have identified a high prevalence of body image dissatisfaction among adolescents, ranging from 60.4 to $64.2 \%$, in which different perceptions were observed between sexes (boys: $54.5 \%$, girls: $65.7 \%$ ), and body image dissatisfaction was present even in adolescents with adequate body mass index (BMI) $(61.5 \%)^{1,3,4}$, demonstrating that other factors may interfere with body image not only body weight perception.

The growing urbanization process was responsible for changes in the lifestyle of adolescents, such as a preference for sedentary activities and inadequate eating habits, which favored the emergence of obesity and other chronic noncommunicable diseases, generating excessive concern with physical appearance ${ }^{4}$. In Brazil, the "nutritional transition" generated an increase in BMI, which does not comply with the culturally established difficultto-obtain beauty pattern ${ }^{5,6}$. In general, girls desire leaner bodies, whereas boys desire stronger and more muscular bodies $^{7,8}$, which are stereotyped by the high influence of media and social networks 9 .

In addition to body image perception, other factors such as bullying were associated with body image dissatisfaction among adolescents ${ }^{10}$. Teasing, considered a normal part of adolescents' development, may become chronic or considered an act of bullying, physical, verbal and relational harassment, which undermine the psychosocial health and general well-being of adolescents ${ }^{10,11}$. Victims of bullying are generally identified as more fragile and perceive themselves as body image dissatisfied ${ }^{12}$. On the other hand, the opposite relationship has also been reported in the literature, that is, young people dissatisfied with their body image, either due to overweight or thinness, were also exposed to bullying, so that the further away from the desired body size, the higher the risk of exposure $^{10}$.

Another fact associated with body image dissatisfaction was behaviors related to weight control ${ }^{13}$. Behaviors such as over-exercising to lose weight, eating less or fre- 
quently eating low-fat foods, fasting for $24 \mathrm{~h}$ or more, taking diet pills, vomiting or taking laxatives to lose or gain weight were more common in adolescents dissatisfied with their body image, both for those dissatisfied due to overweight and those due to thinness ${ }^{13,14}$. These behaviors related to exaggerated body weight control are considered to be harmful to health and cause chronic physical and psychological problems, as adolescents usually do not undergo any professional follow-up ${ }^{13}$.

Given that body image dissatisfaction may impact the physical and mental health of adolescents and that factors such as bullying-related provocations and weightcontrol behaviors are more frequent in young people dissatisfied with their body image, research on this subject may be useful for health and education professionals who work with adolescents in order to guide, prevent and rethink the relationship that adolescents have with their own body. Based on the above, the aims of the study were: 1) to estimate the prevalence of body image dissatisfaction among adolescents; 2) to verify the association between body image dissatisfaction and provocative behaviors among adolescents (making jokes or laughing at their appearance, laugher for being uncoordinated and giving nicknames about their size/body weight) and weight control (maintaining a balanced diet, how to describe bodyweight, took any initiative to change weight, practiced physical exercise to change weight, fasted for $24 \mathrm{~h}$ and vomited/took laxatives to lose weight).

\section{Methods}

\section{Population and sample}

This is a cross-sectional epidemiological study approved by the Ethics Committee on Research with Human Beings of the "Extremo Sul Catarinense" University (protocol No. 1.125.725, June 26, 2015), which integrates the research titled "Association between health status, risk behavior and level of physical activity of schoolchildren from public and private schools in the municipality of Criciúma - SC". Adolescents who participated in the research signed the Assent Form and parents/guardians signed the Free and Informed Consent Form (TCLE).

The population of this study was composed of 17,000 schoolchildren from public and private schools, enrolled from the $5^{\text {th }}$ grade of elementary school to the $3^{\text {rd }}$ year of high school in the municipality of Criciúma, Santa Catarina, Brazil. In order to calculate the sample size of the macroproject, overweight, low levels of physical activity and low levels of aerobic fitness were considered as the main outcomes. Considering previous publications in the municipality under study ${ }^{15,16}$, the prevalence of these outcomes was $30 \%$ (overweight) or $70 \%$ (low levels of physical activity and low levels of aerobic fitness). This prevalence has the same effect in terms of information for the sample size calculation ${ }^{17}$. A $95 \%$ confidence level, the estimated error of five percentage points, design effect of 1.5 , and increase of $20 \%$ for eventual losses and refusals were adopted. Considering these parameters, a sample of 570 adolescents was estimated.

Data collection was performed in the second half of 2015. Questionnaires were administered in the classroom, without the presence of teachers. The team of evaluators participated in previous training to standardize data collection procedures. The following inclusion criteria were used: a) adolescents in the age group from 11 to 17 years; b) absence of health problems that prevented them from performing physical and anthropometric tests. Adolescents who refused to participate in the research and those who did not return the TCLE signed by the parents/guardians were considered denials. Adolescents who did not fill out any of the questionnaire questions were considered losses (Figure 1).

\section{Dependent variable}

Body image was assessed using the scale of silhouettes of Stunkard, Sorenson, and Schulsinger ${ }^{18}$ validated for the Brazilian population as previously described ${ }^{2}$. The instrument is formed by nine figures of body silhouettes for each sex, presented sequentially, in which silhouette number one ${ }^{1}$ represents extreme thinness, while silhouette number nine ${ }^{9}$ represents severe obesity. Adolescents were questioned as to which of the figures best represented their current physical shape (Real Silhouette - RS) and later which of the figures represented the physical form in which they would like to appear (Ideal Silhouette - IS). To determine body image dissatisfaction, the difference between RS and IS (RS - IS) was mathematically verified. The results could range from -8 to +8 , where the higher the results (positive or negative), the farther adolescents were from the silhouette they would like to have. Thus, adolescents with negative results were considered as "dissatisfied due to thinness", positive as "dissatisfied due to overweight", and adolescents with scores equal to zero represented "satisfied" with body image.

\section{Independent variables}

The independent variables of the present study were: teasing behaviors among adolescents (making jokes or laughing at their appearance, laugher for being uncoordinated and giving nicknames about their size/body weight) and weight control (maintaining a balanced diet, how to describe body weight, took any initiative to change weight, practiced physical exercise to change weight, fasted for $24 \mathrm{~h}$ and vomited/took laxatives to lose weight). All variables were collected through self-administered questionnaires.

Teasing behavior among adolescents was measured through the Child-Adolescent Teasing Scale (CATS) ${ }^{11}$, 


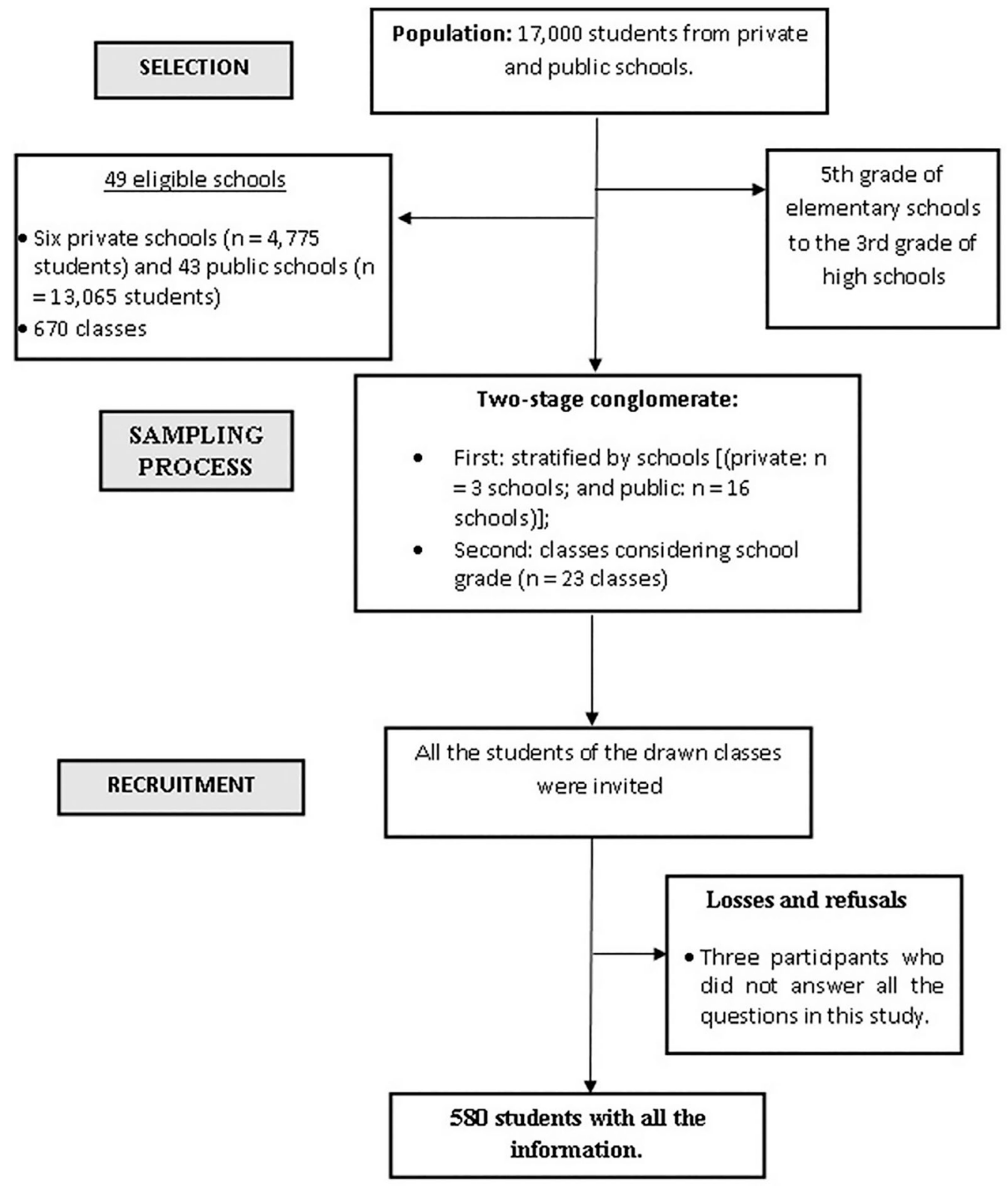

Figure 1 - Flowchart of the sampling process adopted in the present study.

which aims to identify adolescents at risk of bullying. So, variable 'made a joke or laughed at your appearance' was assessed by the question: "Have people ever made a joke or laughed at you because of your appearance?". Variable 'laughed for being uncoordinated' was evaluated by question: "Have people ever made a joke and laughed at you for being uncoordinated?". Finally, the variable 'nickname for size/weight' was evaluated by the question 'Have people ever given you a nickname that refers to your size or weight?'. For these questions, the answer options were: 1) never; 2) almost never; 3) sometimes; 4) almost always; 5) frequently. Answers were categorized as "no" (options 1 and 2) and "yes" (options 3, 4, and 5).
Regarding variables weight control behaviors, a balanced diet was collected using a question that integrates the Fantastic Lifestyle questionnaire ${ }^{19}$ ) translated and validated for the Brazilian population ${ }^{20}$. The question used was "Do you eat a balanced diet?" Answer options: 1) almost never; 2) rarely; 3 ) sometimes; 4) with relative frequency; 5) almost always. Answers were categorized as "no" (options 1 and 2) and "yes" (options 3, 4, and 5).

Variables 'how do you describe your body weight', 'have you taken any initiative to change your bodyweight', 'have you practiced physical exercise to change weight', 'fasted for $24 \mathrm{~h}$ ' and 'vomited/took laxatives to lose weight' were collected through the Youth Risk Beha- 
vior Surveillance Questionnaire (YRBSS), elaborated by Eaton $^{21}$ and translated and validated for Brazil ${ }^{22}$. Body weight description was evaluated by the question "How do you describe your bodyweight?" Answer options: 1) far below what I expect; 2) a little below what I expect; 3) the expected weight, 4) a little above what I expect, 5) much higher than I expect.) Answers were categorized as "underweight" (options 1 and 2), "ideal weight" (options 3 ) and "overweight" (options 4 and 5). Variable on the weight-change initiative was evaluated using the question "Have you taken any initiative to change your body weight?" Answer options: 1) to lose bodyweight; 2) to gain bodyweight; 3) to maintain bodyweight; 4) I did not try any initiative to change my body weight). For the analyses, each response option was considered as a category.

The practice of physical exercise to change weight was collected through the question "During the past 30 days, did you do any type of physical exercise to lose body weight or not to increase body weight?" Answer options: 1) no; 2) yes. Variable fasting for $24 \mathrm{~h}$ was assessed by the question "During the past 30 days, did you fast for $24 \mathrm{~h}$ or more to lose body weight or not to increase body weight?" Answer options: 1) no; 2) yes. Finally, variable vomiting / taking laxatives to lose weight was evaluated by the question "During the last 30 days, did you vomit or take laxatives to lose body weight or not to increase body weight?" Answer options: 1) no; 2) yes.

Age (full years) and sex (boys and girls) were collected using a questionnaire and used as a characterization and stratification variable, respectively.

\section{Statistical analysis}

First, descriptive analysis of data (frequency distribution) and exclusion of observations with missings were carried out, ensuring that models contained the same number of observations. All analyses were stratified according to sex. To estimate differences in the prevalence of body image dissatisfaction according to independent variables, the chi-square test of heterogeneity was applied. Subsequently, multinominal logistic regression was used to verify associations between body image (reference category $=$ satisfied $)$ with behavioral variables and attitudes for weight control, with odds ratio (OR) estimation, and $95 \%$ confidence interval $(95 \% \mathrm{CI})$. In the adjusted analysis, all covariables were inserted into the model (making jokes or laughing at their appearance, laugher for being uncoordinated and giving nicknames about their size/body weight, maintaining a balanced diet, how to describe body weight, took any initiative to change weight, practiced physical exercise to change weight, fasted for $24 \mathrm{~h}$ and vomited / took laxatives to lose weight), regardless of p-value in the crude analysis, remaining in the final model only variables with $p$-value $\leq 0.20$, according to the backward method. Analyses were performed in the Statistical Package for the Social Sciences software (IBM SPSS Statistics, Chicago, USA), version 22.0 , with the significance level set at $5 \%$.

\section{Results}

A total of 580 adolescents with mean age of 14 years participated in the study - boys $(11$ years $=60 ; 12$ years $=26$; 13 years $=39 ; 14$ years $=28 ; 15$ years $=51 ; 16$ years $=45$; 17 years $=33)$; girls $(11$ years $=56 ; 12$ years $=31 ; 13$ years $=$ $32 ; 14$ years $=34 ; 15$ years $=47 ; 16$ years $=61 ; 17$ years $=$ 37). Data not shown in Tables / Figures), the majority girls (51.4\%). Of the total number of adolescents, 282 (48.6\%) were dissatisfied with their body image due to overweight and $133(22.9 \%)$ due to thinness. Among boys, 135 (47.9\%) were dissatisfied due to overweight and $67(23.8 \%)$ due to thinness. Among girls, 147 (49.3\%) were dissatisfied due to overweight and $66(22.1 \%)$ due to thinness. Girls who reported fasting for $24 \mathrm{~h}$ had higher prevalence of dissatisfaction due to thinness $(\mathrm{p}<0.01)$ (Table 1$)$.

For boys, in the crude analysis, none of the behavioral factors or attitudes was associated with body image dissatisfaction. However, the adjusted analysis showed that adolescents who were dissatisfied due to overweight presented a higher odds ratio (OR: $3.00,95 \%$ CI: 1.17-7.67) for being the target of joking and laughing due to their appearance when compared with those satisfied with their body image. In addition, boys dissatisfied due to overweight had a lower odds ratio (OR: $0.35,95 \%$ CI: 0.15 0.82 ) for receiving nicknames due to their body size or body weight when compared with adolescents satisfied with their image body. Boys dissatisfied due to thinness had a higher odds ratio (OR: 2.84, 95\% CI: 1.04-7.79) for being the target of jokes and laugher about their appearance compared with those satisfied with their body image (Table 2).

For girls' adolescents, the crude analysis identified that adolescents dissatisfied due to thinness presented higher odds ratio (OR: 2.54; 95\% CI: 1.58-4.09) for being the target of jokes and laughter because of their appearance when compared with satisfied ones. In addition, those dissatisfied due to overweight were more likely to fasting for $24 \mathrm{~h}$ when compared with those satisfied with their body image. In the adjusted analysis, adolescents dissatisfied due to overweight were more likely to be the target of laugher because they were uncoordinated (OR: 3.21, 95\% CI: 1.01-10.20) and for fasting for $24 \mathrm{~h}$ (OR: 9.86; 95\% CI: 2.04-47.69) when compared with those satisfied with their body image. Girls dissatisfied due to thinness were less likely of being the target of laughter because of their appearance (OR: 0.27 ; 95\% CI: $0.07-$ 0.97). On the other hand, adolescents dissatisfied due to thinning were more likely of being the target of laughter because they were uncoordinated (OR: $5.42,95 \% \mathrm{CI}$ : 1.43-20.61), compared with those satisfied with their body image (Table 3). 
Table 1 - Sample distribution according to body image, stratified by sex, of adolescents enrolled in schools in the municipality of Criciúma, Santa Catarina, Brazil.

\begin{tabular}{|c|c|c|c|c|c|c|c|c|}
\hline \multirow[t]{2}{*}{ Variables } & \multicolumn{3}{|c|}{ Boys Body image $(n=282)$} & \multirow[t]{2}{*}{$\mathbf{p}$} & \multicolumn{3}{|c|}{ Girls Body image $(n=298)$} & \multirow[t]{2}{*}{$\mathbf{p}$} \\
\hline & $\begin{array}{l}\text { Satisfied n } \\
\quad(\%)\end{array}$ & $\begin{array}{l}\text { Dissatisfied due to } \\
\text { overweight n (\%) }\end{array}$ & $\begin{array}{l}\text { Dissatisfied due to } \\
\text { thinness n (\%) }\end{array}$ & & $\begin{array}{l}\text { Satisfied n } \\
\quad(\%)\end{array}$ & $\begin{array}{l}\text { Dissatisfied due to } \\
\text { overweight n (\%) }\end{array}$ & $\begin{array}{l}\text { Dissatisfied due to } \\
\text { thinness n (\%) }\end{array}$ & \\
\hline Total $(n=580)$ & $80(28.4)$ & $135(47.9)$ & $67(23.8)$ & & $85(28.5)$ & $147(49.3)$ & $66(22.1)$ & \\
\hline $\begin{array}{l}\text { Jokes or laughter } \\
\text { about appearance }\end{array}$ & & & & 0.09 & & & & 0.27 \\
\hline No & $68(30.7)$ & $106(48.0)$ & $47(21.3)$ & & $71(29.0)$ & $116(47.3)$ & $58(23.7)$ & \\
\hline Yes & $12(19.7)$ & $29(47.5)$ & $20(32.8)$ & & $14(26.4)$ & $31(58.5)$ & $08(15.1)$ & \\
\hline $\begin{array}{l}\text { Laughter at being } \\
\text { uncoordinated }\end{array}$ & & & & 0.26 & & & & 0.08 \\
\hline No & $71(29.1)$ & $119(48.8)$ & $54(22.1)$ & & $80(30.8)$ & $124(47.7)$ & $56(21.5)$ & \\
\hline Yes & $09(23.7)$ & $16(42.1)$ & $13(34.2)$ & & $05(13.2)$ & $23(60.5)$ & $10(26.3)$ & \\
\hline $\begin{array}{l}\text { Nickname for size / } \\
\text { weight }\end{array}$ & & & & 0.07 & & & & 0.47 \\
\hline No & $59(27.6)$ & $110(51.4)$ & $45(21.0)$ & & $67(27.8)$ & $123(51.0)$ & $51(21.2)$ & \\
\hline Yes & $21(30.8)$ & $25(36.8)$ & $22(32.4)$ & & $18(31.6)$ & $24(42.1)$ & $15(26.3)$ & \\
\hline Balanced diet & & & & 0.71 & & & & 0.99 \\
\hline No & $43(29.2)$ & $67(45.6)$ & $37(25.2)$ & & $44(28.4)$ & $77(49.7)$ & $34(21.9)$ & \\
\hline Yes & $37(27.4)$ & $68(50.4)$ & $30(22.2)$ & & $41(28.6)$ & $70(49.0)$ & $32(22.4)$ & \\
\hline $\begin{array}{l}\text { Body weight descrip- } \\
\text { tion }\end{array}$ & & & & 0.95 & & & & 0.56 \\
\hline Underweight & $16(27.6)$ & $28(48.3)$ & $14(24.1)$ & & $12(21.0)$ & $33(57.9)$ & $12(21.1)$ & \\
\hline Ideal weight & $37(28.7)$ & $64(49.6)$ & $28(21.7)$ & & $33(32.3)$ & $48(47.1)$ & $21(20.6)$ & \\
\hline Overweight & $27(28.4)$ & $43(45.3)$ & $25(26.3)$ & & $40(28.8)$ & $66(47.5)$ & $33(23.7)$ & \\
\hline $\begin{array}{l}\text { Initiative to change } \\
\text { weight }\end{array}$ & & & & 0.51 & & & & 0.52 \\
\hline Lose weight & $29(31.1)$ & $38(40.9)$ & $26(28.0)$ & & $44(30.7)$ & $68(47.6)$ & $31(21.7)$ & \\
\hline Gain weight & $17(31.5)$ & $28(51.9)$ & 09 (16.7) & & $13(27.6)$ & $21(44.7)$ & $13(27.7)$ & \\
\hline Maintain weight & $13(21.3)$ & $34(55.7)$ & $14(23.0)$ & & $10(24.4)$ & $19(46.3)$ & $12(29.3)$ & \\
\hline $\begin{array}{l}\text { I did not take any initia- } \\
\text { tive }\end{array}$ & $21(28.4)$ & $35(47.3)$ & $18(24.3)$ & & $18(26.9)$ & $39(58.2)$ & $10(14.9)$ & \\
\hline $\begin{array}{l}\text { Physical exercise to } \\
\text { change weight }\end{array}$ & & & & 0.84 & & & & 0.71 \\
\hline No & $55(29.4)$ & $89(47.6)$ & $43(23.0)$ & & $51(27.1)$ & $96(51.1)$ & $41(21.8)$ & \\
\hline Yes & $25(26.3)$ & $46(48.4)$ & $24(25.3)$ & & $34(30.9)$ & $51(46.4)$ & $25(22.7)$ & \\
\hline Fasting for $24 \mathrm{~h}$ & & & & 0.80 & & & & $<0.01$ \\
\hline No & $07(25.0)$ & $13(46.4)$ & $08(28.6)$ & & $12(52.2)$ & $04(17.4)$ & $07(30.4)$ & \\
\hline Yes & $73(28.8)$ & $122(48.0)$ & $59(23.2)$ & & $73(26.5)$ & $143(52.0)$ & $59(21.5)$ & \\
\hline $\begin{array}{l}\text { Vomiting / taking } \\
\text { laxatives to lose } \\
\text { weight }\end{array}$ & & & & 0.56 & & & & 0.55 \\
\hline No & $78(28.8)$ & $128(47.2)$ & $65(24.0)$ & & $81(28.3)$ & $141(49.1)$ & $65(22.6)$ & \\
\hline Yes & $02(18.2)$ & 07 (63.6) & $02(18.2)$ & & $04(36.4)$ & $06(54.5)$ & $01(9.1)$ & \\
\hline
\end{tabular}

\section{Discussion}

The main findings of this study were: 1) approximately one in two boys were dissatisfied due to overweight, while one in four were dissatisfied due to thinness; 2) approximately one in two girls adolescents were dissatisfied due to overweight, while one in five were dissatisfied due to thinness; 3) boys dissatisfied due to overweight and those dissatisfied due to thinness were more likely to be the target of jokes about their appearance, and those who were dissatisfied due to overweight were less likely to receive nicknames 
Table 2 - Crude and adjusted multinomial logistic regression analysis between body image and behaviors and attitudes for weight control in boys from the municipality of Criciúma, Santa Catarina, Brazil.

\begin{tabular}{|c|c|c|c|c|c|c|c|c|c|c|c|c|}
\hline \multicolumn{13}{|c|}{ Boys (n 282) } \\
\hline \multicolumn{6}{|c|}{ Dissatisfied due to overweight } & \multicolumn{7}{|c|}{ Dissatisfied due to thinness } \\
\hline Variables & OR & $\begin{array}{c}\text { Crude analysis } \\
(95 \% \mathrm{CI})\end{array}$ & $\mathbf{p}$ & OR & $\begin{array}{c}\text { Adjusted analy- } \\
\text { sis * }(95 \% \mathrm{CI})\end{array}$ & $\mathbf{p}$ & OR & $\begin{array}{c}\text { Crude analysis } \\
(95 \% \mathrm{CI})\end{array}$ & $\mathbf{p}$ & OR & $\begin{array}{c}\text { Adjusted ana- } \\
\text { lysis* }(95 \% \mathrm{CI})\end{array}$ & $\mathbf{p}$ \\
\hline $\begin{array}{l}\text { Jokes or laugher at } \\
\text { appearance }\end{array}$ & & & 0.09 & & & 0.04 & & & 0.09 & & & 0.04 \\
\hline No & 1 & & & 1 & & & 1 & & & 1 & & \\
\hline Yes & 1.35 & $(0.67-2.72)$ & & 3.00 & $(1.17-7.67)$ & & 0.70 & $(0.27-1.78)$ & & 2.84 & $(1.04-7.79)$ & \\
\hline $\begin{array}{l}\text { Laugher for being unco- } \\
\text { ordinated }\end{array}$ & & & 0.28 & & & 0.86 & & & 0.28 & & & 0.86 \\
\hline No & 1 & & & 1 & & & 1 & & & 1 & & \\
\hline Yes & 1.06 & $(0.44-2.53)$ & & 1.00 & $(0.36-2.78)$ & & 1.90 & $(0.76-4.77)$ & & 1.29 & $(0.44-3.80)$ & \\
\hline $\begin{array}{l}\text { Nickname for size / } \\
\text { weight }\end{array}$ & & & 0.07 & & & 0.03 & & & 0.07 & & & 0.59 \\
\hline No & 1 & & & 1 & & & 1 & & & 1 & & \\
\hline Yes & 0.64 & $(0.33-1.24)$ & & 0.35 & $(0.15-0.82)$ & & 1.37 & $(0.67-2.80)$ & & 0.78 & $(0.31-1.93)$ & \\
\hline Balanced diet & & & 0.71 & & & 0.72 & & & 0.71 & & & 0.72 \\
\hline No & 1 & & & 1 & & & 1 & & & 1 & & \\
\hline Yes & 0.85 & $(0.49-1.48)$ & & 0.88 & $(0.50-1.55)$ & & 1.06 & $(0.55-2.04)$ & & 1.12 & $(0.58-2.18)$ & \\
\hline Body weight description & & & 0.95 & & & 0.96 & & & 0.95 & & & 0.96 \\
\hline Ideal weight & 1 & & & 1 & & & 1 & & & 1 & & \\
\hline Overweight & 0.92 & $(0.49-1.73)$ & & 1.05 & $(0.48-2.29)$ & & 1.22 & $(0.59-2.55)$ & & 1.12 & $(0.45-2.75)$ & \\
\hline Underweight & 1.01 & $(0.48-2.11)$ & & 1.31 & $(0.57-2.98)$ & & 1.15 & $(0.48-2.76)$ & & 1.40 & $(0.53-3.66)$ & \\
\hline $\begin{array}{l}\text { Initiative to change } \\
\text { weight }\end{array}$ & & & 0.48 & & & 0.47 & & & 0.48 & & & 0.47 \\
\hline No initiative & 1 & & & 1 & & & 1 & & & 1 & & \\
\hline Lose weight & 0.79 & $(0.38-1.62)$ & & 0.76 & $(0.36-1.59)$ & & 1.05 & $(0.46-2.38)$ & & 0.93 & $(0.40-2.14)$ & \\
\hline Gain weight & 0.99 & $(0.44-2.22)$ & & 0.96 & $(0.42-2.19)$ & & 0.62 & $(0.22-1.72)$ & & 0.60 & $(0.21-1.69)$ & \\
\hline Maintain weight & 1.56 & $(0.68-3.62)$ & & 1.66 & $(0.71-3.88)$ & & 1.26 & $(0.47-3.36)$ & & 1.26 & $(0.47-3.41)$ & \\
\hline $\begin{array}{l}\text { Physical exercise to } \\
\text { change weight }\end{array}$ & & & 0.83 & & & 0.89 & & & & & & 0.89 \\
\hline No & 1 & & & 1 & & & 1 & & & 1 & & \\
\hline Yes & 1.14 & $(0.63-2.05)$ & & 1.17 & $(0.61-2.25)$ & & 1.22 & $(0.68-2.44)$ & & 1.12 & $(0.53-2.38)$ & \\
\hline Fasting for $24 \mathrm{~h}$ & & & 0.80 & & & 0.95 & & & 0.80 & & & 0.95 \\
\hline No & 1 & & & 1 & & & 1 & & & 1 & & \\
\hline Yes & 0.90 & $(0.34-2.36)$ & & 0.94 & $(0.32-2.77)$ & & 0.71 & $(0.24-2.06)$ & & 0.82 & $(0.25-2.69)$ & \\
\hline $\begin{array}{l}\text { Vomiting / taking laxa- } \\
\text { tives to lose weight }\end{array}$ & & & 0.55 & & & 0.64 & & & 0.55 & & & 0.64 \\
\hline No & 1 & & & 1 & & & 1 & & & 1 & & \\
\hline Yes & 2.13 & $(0.43-10.53)$ & & 1.80 & $(0.33-9.69)$ & & 1.20 & $(0.16-8.76)$ & & 0.91 & $(0.12-7.12)$ & \\
\hline
\end{tabular}

OR - Odds Ratio; 95\% CI - Confidence Interval; *: Analysis adjusted by all covariates. Final models composed of variables: jokes or laugher about appearance and nickname regarding size / weight; reference category = satisfied with body image.

due to their body shape when compared to those satisfied with their body image; 4) girls dissatisfied due to overweight were more likely of being the target of laugher because they were uncoordinated and those who fasted for $24 \mathrm{~h}$, while those dissatisfied due to thinness were less likely of being the target of jokes and laugher because of their appearance and greater chances of being the target of laugher because they are uncoordinated when compared with those satisfied with their body image. 
Table 3 - Crude and adjusted multinomial logistic regression analysis between body image and behaviors and attitudes for weight control in girls' adolescents from the municipality of Criciúma, Santa Catarina, Brazil.

\begin{tabular}{|c|c|c|c|c|c|c|c|c|c|c|c|c|}
\hline \multicolumn{13}{|c|}{ Girls (n 298) } \\
\hline \multicolumn{6}{|c|}{ Dissatisfied due to overweight } & \multicolumn{7}{|c|}{ Dissatisfied due to thinness } \\
\hline Variables & OR & $\begin{array}{l}\text { Crude analy- } \\
\text { sis }(95 \% \mathrm{CI})\end{array}$ & $\mathbf{p}$ & OR & $\begin{array}{l}\text { Adjusted analy- } \\
\text { sis * }(95 \% \mathrm{CI})\end{array}$ & $\mathbf{p}$ & OR & $\begin{array}{l}\text { Crude analy- } \\
\text { sis }(95 \% \mathrm{CI})\end{array}$ & $\mathbf{p}$ & OR & $\begin{array}{l}\text { Adjusted analy- } \\
\text { sis * }(95 \% \mathrm{CI})\end{array}$ & $\mathbf{p}$ \\
\hline $\begin{array}{l}\text { Jokes or laugher at } \\
\text { appearance }\end{array}$ & & & 0.25 & & & 0.65 & & & $<0.01$ & & & 0.02 \\
\hline No & 1 & & & 1 & & & 1 & & & 1 & & \\
\hline Yes & 1.55 & $(0.74-3.24)$ & & 1.24 & $(0.48-3.24)$ & & 2.54 & $(1.58-4.09)$ & & 0.27 & $(0.07-0.97)$ & \\
\hline $\begin{array}{l}\text { Laughed for being } \\
\text { uncoordinated }\end{array}$ & & & 0.06 & & & 0.03 & & & 0.06 & & & 0.03 \\
\hline No & 1 & & & 1 & & & 1 & & & 1 & & \\
\hline Yes & 2.97 & $(1.08-8.12)$ & & 3.21 & $(1.01-10.20)$ & & 2.86 & $(0.93-8.81)$ & & 5.42 & $(1.43-20.61)$ & \\
\hline $\begin{array}{l}\text { Nickname for size / } \\
\text { weight }\end{array}$ & & & 0.46 & & & 0.05 & & & 0.46 & & & 0.05 \\
\hline No & 1 & & & 1 & & & 1 & & & 1 & & \\
\hline Yes & 0.73 & $(0.37-1.43)$ & & 0.50 & $(0.21-1.18)$ & & 1.09 & $(0.50-2.38)$ & & 1.44 & $(0.56-3.70)$ & \\
\hline Balanced diet & & & 0.99 & & & 0.99 & & & 0.99 & & & 0.99 \\
\hline No & 1 & & & 1 & & & 1 & & & 1 & & \\
\hline Yes & 1.02 & $(0.60-1.75)$ & & 0.99 & $(0.56-1.75)$ & 0.97 & 0.99 & $(0.52-1.88)$ & & 1.04 & $(0.53-2.04)$ & \\
\hline $\begin{array}{l}\text { Body weight descrip- } \\
\text { tion }\end{array}$ & & & 0.55 & & & 0.25 & & & 0.55 & & & 0.25 \\
\hline Ideal weight & 1 & & & 1 & & & 1 & & & 1 & & \\
\hline Overweight & 1.13 & $(0.63-2.05)$ & & 1.14 & $(0.55-2.31)$ & & 1.29 & $(0.63-2.65)$ & & 1.46 & $(0.63-3.41)$ & \\
\hline Underweight & 1.89 & $(0.85-4.19)$ & & 2.56 & $(1.02-6.42)$ & & 1.57 & $(0.60-4.14)$ & & 1.55 & $(0.52-4.67)$ & \\
\hline \multicolumn{13}{|l|}{$\begin{array}{l}\text { Initiative to change } \\
\text { weight }\end{array}$} \\
\hline No initiative & 1 & & 0.51 & 1 & & 0.42 & 1 & & 0.51 & 1 & & 0.42 \\
\hline Lose weight & 0.33 & $(0.36-1.40)$ & & 0.67 & $(0.33-1.37)$ & & 0.60 & $(0.52-3.12)$ & & 1.18 & $(0.46-3.06)$ & \\
\hline Gain weight & 0.52 & $(0.31-1.81)$ & & 0.71 & $(0.29-1.77)$ & & 0.29 & $(0.60-5.35)$ & & 1.69 & $(0.55-5.18)$ & \\
\hline Maintain weight & 0.79 & $(0.34-2.26)$ & & 0.85 & $(0.32-2.22)$ & & 0.19 & $(0.69-6.76)$ & & 2.42 & $(0.76-7.80)$ & \\
\hline $\begin{array}{l}\text { Physical exercise to } \\
\text { change weight }\end{array}$ & & & 0.71 & & & 0.79 & & & 0.71 & & & 0.79 \\
\hline No & 1 & & & 1 & & & 1 & & & 1 & & \\
\hline Yes & 0.80 & $(0.46-1.38)$ & & 0.82 & $(0.43-1.57)$ & & 0.91 & $(0.47-1.77)$ & & 0.99 & $(0.47-2.07)$ & \\
\hline Fasting for $24 \mathrm{~h}$ & & & $<0.01$ & & & $<0.01$ & & & 0.96 & & & 0.95 \\
\hline No & 1 & & & 1 & & & 1 & & & 1 & & \\
\hline Yes & 5.88 & $(1.83-18.86)$ & & 9.86 & $(2.04-47.69)$ & & 1.39 & $(0.51-3.74)$ & & 0.96 & $(0.32-2.90)$ & \\
\hline $\begin{array}{l}\text { Vomiting / taking laxa- } \\
\text { tives to lose weight }\end{array}$ & & & 0.49 & & & 0.07 & & & 0.49 & & & 0.07 \\
\hline No & 1 & & & 1 & & & 1 & & & 1 & & \\
\hline Yes & 0.86 & $(0.24-3.14)$ & & 3.78 & $(0.58-24.57)$ & & 0.31 & $(0.03-2.85)$ & & 0.28 & $(0.03-3.10)$ & \\
\hline
\end{tabular}

In the present study, almost half of the boys were dissatisfied due to overweight. A study conducted in 2008 with Brazilian adolescents from the regions of Santa Catarina and Rio Grande do Sul found a prevalence of $20 \%$ of dissatisfaction due to overweight among boys. This difference between studies possibly occurred due to the period in which studies were carried out (2008 and 2015), since, in recent years, adolescents have changed their lifestyle, especially in relation to inadequate eating habits and greater exposure to sedentary activities ${ }^{4}$. These changes have led to the growing increase in body weight and increased vulnerability to obesity-related problems in this population. 
One in four boys were dissatisfied due to thinness in the present study. A similar result was identified in a study with rural and urban adolescents from Santa Catarina, Brazil, where $26.4 \%$ of adolescents who wanted stronger bodies were dissatisfied due to thinness ${ }^{1}$. Body image dissatisfaction among boys may be related to the constant desire to increase muscle mass and strength, attributes that are directly associated with peer acceptance and acceptance in sports practice ${ }^{23}$. In adolescence, sports are seen as competition with peers and show who is the "best" or "the strongest" or "the most athletic" 24 . This competition represents survival among boys and, thus, thinness is considered a synonym of weakness and, consequently, promotes body image dissatisfaction ${ }^{24}$. In addition, dissatisfaction due to thinness may be related to the accelerated growth of the different body regions that occurs more quickly among boys, which generates little sensitivity in perceiving changes in the dimensions of their own body and causes constant changes in body image construction $^{4,7,25}$.

Among girls, approximately one in two was dissatisfied due to the overweight. Similar results were presented in other studies in Brazil ${ }^{1,4}$. The high prevalence of body image dissatisfaction due to the overweight in girls can also be associated wich changed their lifestyle inappropriate eating behaviors and exposure to sedentary activities, that are more prevalent in females ${ }^{4}$. For girls the concern with physical appearance, increasingly evident in contemporary society, increases social and mediatic pressure, being responsible for the desire to reach a thin silhouette, considered ideal body ${ }^{4,26}$. The distorted view of body size leads to distorted behaviors, such as fasting, provoking vomiting, use of laxatives and diuretics, as well as the feeling of shame from exposing your body, abstaining from leisure practices ${ }^{25}$. Additionally, the growth curves for height and body weight observed in adolescents from five Brazilian regions ${ }^{5}$ were similar or superior to the reference physical growth curves proposed by the World Health Organization (WHO) and by the Health Centers. Disease Control and Prevention (CDC), showing that in fact a growing scenario of overweight among Brazilian girls, which can potentiate dissatisfaction with being overweight and, consequently, harmful health behaviors in the search for an increasingly slim body.

One in four girls presented body image dissatisfaction due to thinness in the present study. A similar result was identified in a study carried out with adolescents from military schools in the municipality of Fortaleza, Ceará, Brazil, in which even adolescents with adequate nutritional status presented body image dissatisfaction due to thinness ${ }^{27}$. The fact that adolescents presented body image dissatisfaction due to thinness can be justified by the lower body awareness associated with low self-esteem and social charges that remain even if they are within culturally accepted beauty patterns ${ }^{27}$.
Regarding teasing attitudes among adolescents, the present study observed that boys dissatisfied due to overweight and thinness were more likely to be the target of jokes and laugher because of their appearance compared to those satisfied with their body image. In Slovakia, body dissatisfaction among adolescents was directly associated with bullying behaviors in peer relationships ${ }^{28}$. Furthermore, the study reported that those dissatisfied due to overweight and thinness were more likely to become bullying passive or reactive victims because they were more vulnerable due to different appearances, low self-esteem, and social dysfunction which may explain in part the results found ${ }^{28}$. No similar studies found in Brazil.

Boys dissatisfied due to overweight were less likely to receiving nicknames due to their size or body weight when compared with those satisfied with their body image in the present study. Similar studies were not found in Brazil, but a Danish study found that boys aged 11 to 15 years increased the chances of exposure to bullying, as they increased the degree of dissatisfaction with body image, both due to the overweight and thinness, when compared with boys satisfied with their body image ${ }^{10}$. In addition, boys who consider their body very thin were seven times more likely to be exposed to bullying, when compared with boys satisfied with their body image, and twice more likely when compared with boys dissatisfied because they considered their body too fat ${ }^{10}$. A possible explanation for this result is, among boys, the thin body is indicative of weakness, while the larger body size is indicative of being physically strong ${ }^{10}$. Thus, despite being dissatisfied with their own body image due to the excess weight, possibly the body volume of these adolescents inhibits the action of the aggressors.

In the present study, girls dissatisfied due to the thinness were less likely of being the target of jokes and laughter because of their appearance when compared to those satisfied with their body image. A study with adolescents from Slovakia found no association between selfreported thinness and being a victim of bullying among girls ${ }^{28}$. The result of the present study can be explained by the cultural and historical change in the girls' beauty pattern, that leaner bodies must come to be considered the social pattern, and such pattern is stimulated and transmitted by the media and social networks ${ }^{7,29}$. In this sense, girls dissatisfied due to the thinness do not seem to suffer bullying from their peers and such dissatisfaction leads to an incessant search more perfect bodies, according to standards set by current society. Thus, dissatisfaction with thinness may be associated with or desire to increase muscle mass or volume in some specific region of the body ${ }^{24}$.

In addition, girls dissatisfied due to overweight and thinness were more likely to be the target of laugher because they were uncoordinated when compared to those satisfied with their body image. A study with adolescents from the Rio Grande do Sul, Brazil, highlighted that bul- 
lying in relation to body shape, either due to overweight or thinness, considered outside the beauty patterns, occurs mainly during Physical Education classes and school recess, and occurs in a verbal way and by means of exclu$\operatorname{sions}^{30}$. Thus, bullying victims seek isolation by remaining mainly in sedentary behaviors and physical inactivity, so that they become less active and consequently have fewer motor experiences, which leads to a higher level of incoordination, becoming a target for aggressors ${ }^{30,31}$.

Regarding behaviors for body weight change, girls dissatisfied due to overweight were more likely to fasting for $24 \mathrm{~h}$ when compared with adolescents satisfied with their body image. This result is three times higher than that found in a study with a sample of students aged 1519 years in a survey conducted in Brazil ${ }^{13}$, possibly due to age differences. Fasting for $24 \mathrm{~h}$ or more is more frequent in girls and may be associated with cultural and historical influences, which connect with beauty standards of a lean body ${ }^{29}$.

The identification of the prevalence of body image dissatisfaction (both due to overweight and thinness) and the association with teasing behaviors and body weight control in adolescents of both sexes are strengths of this study. The different factors investigated in a single analysis model and the representative sample of adolescents from the municipality of Criciúma, southern Brazil, is also considered a strong point of the study. Most studies found did not investigate the association between teasing and weight control variables, which may change the results. Aspects of weight control such as cessation of eating and taking weight-loss medications are related to eating disorders that can be potentialized with their bullying.

This study presents limitations: 1) the cross-sectional design that does not allow cause and effect relationship; 2) the lack of information about sexual maturation, age control and economic conditions of participants that influenced body image; 3 ) the use of subjective measures such as questionnaires may present memory bias; 4) the figures of silhouettes that, although widely used in literature, do not differ among age groups during adolescence, and are formed by two-dimensional figures in black and white scale; 5) the question that defined the "exercise to change weight" variable did not investigate whether adolescents who exercised to increase body weight; 6) the variable question "fasting for $24 \mathrm{~h}$ " did not identify who would like to increase body weight to increase muscle mass or another component of body composition; 7) the question "During the past 30 days, did you do any kind of physical exercise to lose body weight or not to increase body weight?" did not ask about adolescents who exercised to increase body weight; 8) the question "During the past 30 days, did you fast for $24 \mathrm{~h}$ or more to lose body weight or not to increase body weight?" did not ask those who increased their caloric intake, made use of supplements and / or dietary supplements.
It could be concluded that more than half of adolescents of both sexes are dissatisfied with their body image, mainly due to overweight. For boys, those dissatisfied due to overweight and to thinness were associated with being the target of jokes and laugher, and those dissatisfied due to overweight were more likely of receiving nicknames due to size or body weight. For girls, factors associated with being overweight were the reasons that they were targets of laughter because they were uncoordinated and fasted for $24 \mathrm{~h}$, while those who were unsatisfied due to thinness were associated with laughter because they were uncoordinated and were likely of being the target of jokes and laughter due to their appearance. Thus, the results can be used to monitor the subgroups with greater chances of dissatisfaction with body image, with the objective of directing strategies intervention in the school environment, in an attempt to provide a follow-up for these adolescents, counting on the integrated action of the sectors of the health and education.

\section{Practical applications}

Based on the results of the present study high prevalence of body image dissatisfaction and the association with provocative behaviors and body weight control in adolescents of both sexes, help school health professionals to identify subgroups with greater susceptibility of being dissatisfied with excess weight and thinness, which is important because these extremes are directly associated with mental illness and eating disorders such as bulimia, anorexia and vigorexia. Also, our findings contribute to adolescents, as a co-responsible for their health, to understand the elements that can generate dissatisfaction with their own body, so they may feel motivated to have attitudes to prevent eating disorders.

According to the Program for International Student Assessment (PISA) ${ }^{31}$ in Brazil, $17.5 \%$ of adolescents claim they suffered some form of bullying "a few times a month"; $7.8 \%$ said they were excluded by colleagues; $9.3 \%$, to be joked; $4.1 \%$, to be threatened; $3.2 \%$, pushed and physically assaulted. In addition, another $5.3 \%$ said colleagues often pick up and destroy their stuff and 7.9\% are rumored to be malicious. Based on the students' reports, $9 \%$ were classified in the study as frequent victims of bullying, that means, they are at the top of the indicator of aggression and more exposed to this situation, which can lead these adolescents to suicidal thoughts and attitudes inside or outside of the school environment. Thus, it is emerging that the responsible parts of the scholar's health such as the school, family context, philanthropic organizations, health, and education organs and the adolescent himself, seek help and training to deal with.

Additionally, body image is a multifactorial construct and therefore should be understood as such. PISA ${ }^{32}$. Also, it showed that parents and teachers represent an important role in student well-being, and whose students 
who have parents interested in school activities are less likely to feel alone in school and less likely to be dissatisfied with life. In addition, students who receive support and support from classroom teachers are more likely to feel they belong to the school than those who do not. Thus, educational management government agencies, school itself and adolescent health surveillance agencies should invest in multicomponent actions, based on theoretical models of behavior change, which may reflect greater satisfaction with body image, containing elements how: healthy weight control; healthy eating practice; increased level of physical activity; fight against bullying; specialized support for cases of depression and suicidal thoughts; excessive media exposure; among other aspects may be related body image dissatisfaction.

\section{References}

1. Petroski EL, Pelegrini A, Glaner MF. Motivos e prevalência de insatisfação com a imagem corporal em adolescentes. Cien Saude Colet. 2012; 17(4):1071-1077.

2. Scagliusi FB, Alvarenga M, Polacow VO, Cordás TA, de Oliveira Queiroz GK, Coelho D, et al. Concurrent and discriminant validity of the Stunkard's figure rating scale adapted into Portuguese. Appetite. 2006;47(1):77-82.

3. Marques MI, Pimenta J, Reis S, Ferreira LM, Peralta L, Santos MI, et al. (In) Satisfação com a imagem corporal na adolescência. Nascer E Crescer. 2016;25(4):217-221.

4. Petroski EL, Pelegrini A, Glaner MF. Insatisfação corporal em adolescentes rurais e urbanos. Motricidade. 2009;5 (4):13-25.

5. Silva DAS, Pelegrini A, Petroski EL, Gaya ACA. Comparison between the growth of Brazilian children and adolescents and the reference growth charts: data from a Brazilian project. J Pediatr (Rio J). 2010;86(2):115-120.

6. de Souza EB. Transição nutricional no Brasil: análise dos principais fatores. Cad UniFOA. 2017;5(13):49-53.

7. Pereira ÉF, Graup S, Lopes A da S, Borgatto AF, Daronco LSE. Body image perception in children and adolescents with different socio-economic status in the city of Florianópolis, in the state of Santa Catarina, Brazil. Rev Bras Saúde Mater Infant. 2009;9(3):253-262.

8. Felden ÉPG, Claumann GS, Sacomori C, Daronco LSE, Cardoso FL, Pelegrini A. Fatores sociodemográficos e imagem corporal em adolescentes do ensino médio. Cien Saude Colet. 2015; 20:3329-3337.

9. Lira AG, Ganen A de P, Lodi AS, Alvarenga M dos S. Uso de redes sociais, influência da mídia e insatisfação com a imagem corporal de adolescentes brasileiras. J Bras Psiquiatr. 2017;66(3):164-171.

10. Brixval CS, Rayce SL, Rasmussen M, Holstein BE, Due P. Overweight, body image and bullying - an epidemiological study of 11-to 15-years olds. Eur J Public Health. 2011;22 (1):126-130.

11. Vessey JA, Horowitz JA, Carlson KL, Duffy M. Psychometric Evaluation of the Child-Adolescent Teasing Scale. J Sch Health. 2008;78(6):344-350.
12. Barbosa AAD, Soares MS, Pereira JM. Características associadas a vítimas de bullying nas escolas brasileiras. Rev Univ Vale Rio Verde. 2018 Jan 3;15(2):791-799.

13. Frank R, Claumann GS, Felden ÉP, Silva DA, Pelegrini A. Body weight perception and body weight control behaviors in adolescents. J Pediatr 2018;94(1):40-47.

14. Ursoniu S, Putnoky S, Vlaicu B. Body weight perception among high school students and its influence on weight management behaviors in normal weight students: a crosssectional study. Wien Klin Wochenschr. 2011;123(1112):327-333.

15. de Oliveira G, Silva DAS, Maggi RM, Petroski EL, de Farias JM. Fatores sociodemográficos e de aptidão física associados a baixos níveis de atividade física em adolescentes de uma cidade do Sul do Brasil. Rev Edu Fis. 2012;23(4):635645.

16. Silva DAS, Teixeira DM, De Oliveira G, Petroski EL, de Farias JM. Aerobic fitness in adolescents in southern Brazil: Association with sociodemographic aspects, lifestyle and nutritional status. Rev Andal Med Deporte. 2016;9(1):1722.

17. Luiz RR, Magnanini MM. A lógica da determinaçäo do tamanho da amostra em investigaçöes epidemiológicas. Cad Saúde Colet. 2000;8(2):9-28.

18. Stunkard A, Sorensen T, Schulsinger F. Use of the Danish Adoption Register for the study of obesity and thinness. In: Kety SS, Rowland LP, Sidman RL, Matthysse SW, editors. The genetics of neurological and psychiatric disorders. New York: Raven Press; 1983. p. 115-120.

19. Wilson DM, Nielsen E, Ciliska D. Lifestyle assessment: testing the fantastic instrument. Can Fam Physician. 1984; 30:1863.

20. Añez CRR, Reis RS, Petroski EL. Versão brasileira do questionário "Estilo de Vida Fantástico": tradução e validação para adultos jovens. Arq Bras Cardiol. 2008;91(2):102-109.

21. Eaton DK, Kann L, Kinchen S, Shanklin S, Ross J, Hawkins $\mathrm{J}$, et al. Youth risk behavior surveillance-United States, 2009. MMWR Surveill Summ. 2010;59(5):1-142.

22. Guedes DP, Lopes CC. Validação da versão brasileira do youth risk behavior survey 2007. Rev Saúde Publ. 2010; 44:840-850.

23. Jones DC, Bain N, King S. Weight and muscularity concerns as longitudinal predictors of body image among early adolescent boys: A test of the dual pathways model. Body Image. 2008;5(2):195-204.

24. Cash TF, Smolak L. Body image: A handbook of science, practice, and prevention. Guilford Press; 2011.

25. Dantas RPN de C, Simões TB dos S, Santos PGMD dos, Dantas PM da S, Cabral BGAT. Satisfação da imagem corporal em adolescentes com diferentes estágios de maturação. J Hum Growth Dev. 2017;27(3):300-306.

26. Alves D, Pinto M, Alves S, Mota A, Leirós V. Cultura e imagem corporal. Motricidade. 2009;5(1):1-20.

27. Alves FR, Bezerra FÉ de L, Souza EA de, Teixeira FAA. Imagem corporal e fatores associados em meninas de escolas militares. Rev Bras Promoç Saúde. 2017;30(4):1-7.

28. Holubcikova J, Kolarcik P, Geckova AM, Van Dijk JP, Reijneveld SA. Is subjective perception of negative body image among adolescents associated with bullying? Eur J Pediatr. 2015;174(8):1035-1041. 
29. Legnani RFS, Legnani E, Pereira EF, Gasparotto G da S, Vieira LF, Campos W de. Transtornos alimentares e imagem corporal em acadêmicos de Educação Física. Motriz. 2012;18(1):84-91.

30. Rech RR, Halpern R, Tedesco A, Santos DF. Prevalence and characteristics of victims and perpetrators of bullying. $\mathrm{J}$ Pediatr 2013;89(2):164-170.

31. Sá CSC, Carvalho B, Mazzitelli C. Equilíbrio e coordenação motora em escolares praticantes e não praticantes de atividades física e/ou lúdica extra-escolar. Rev Neurociên. 2014;22(1):29-36.

32. Organization for Economic Co-operation and Development (OECD). Program for International Student Assessment (PISA) 2015 database. 2016.

\section{Corresponding author}

Diego Augusto Santos Silva Universidade Federal de Santa Catarina, Centro de Desportos, Departamento de Educação Física, Campus Universitário Trindade, CEP 88040-900, Florianópolis, SC, Brasil.

E-mail: diegoaugustoss@yahoo.com.br

Manuscript received on November 2, 2019

Manuscript accepted on March 15, 2020

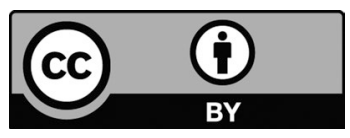

Motriz. The Journal of Physical Education. UNESP. Rio Claro, SP, Brazil - eISSN: 1980-6574 - under a license Creative Commons - Version 4.0 